Louisiana State University

LSU Digital Commons

$10-12-2004$

\title{
Studies of contribution of metals bonded with organic matter of seawater to the fluxes of total dissolved metals across water- sediment interface at Vistula Lagoon of Baltic Sea
}

S. V. Pakhomova

P.P.Shirshov Institute of Oceanology, Russian Academy of Sciences

M. Yu Kononets

P.P.Shirshov Institute of Oceanology, Russian Academy of Sciences

M. V. Yudin

P.P.Shirshov Institute of Oceanology, Russian Academy of Sciences

A. V. Vershinin

P.P.Shirshov Institute of Oceanology, Russian Academy of Sciences

Follow this and additional works at: https://digitalcommons.Isu.edu/biosci_pubs

\section{Recommended Citation}

Pakhomova, S., Kononets, M., Yudin, M., \& Vershinin, A. (2004). Studies of contribution of metals bonded with organic matter of seawater to the fluxes of total dissolved metals across water-sediment interface at Vistula Lagoon of Baltic Sea. USA-Baltic International Symposium: https://doi.org/10.1109/ BALTIC.2004.7296826

This Conference Proceeding is brought to you for free and open access by the Department of Biological Sciences at LSU Digital Commons. It has been accepted for inclusion in Faculty Publications by an authorized administrator of LSU Digital Commons. For more information, please contact ir@lsu.edu. 


\title{
STUDIES OF CONTRIBUTION OF METALS BONDED WITH ORGANIC MATTER OF SEAWATER TO THE FLUXES OF TOTAL DISSOLVED METALS ACROSS WATER-SEDIMENT INTERFACE AT VISTULA LAGOON OF BALTIC SEA
}

\author{
S. V. Pakhomova, M. Yu. Kononets, M. V. Yudin and A. V. Vershinin \\ P.P. Shirshov Institute of Oceanology, RAS, 117997, Nakhimovskii prosp. 36, Moscow, Russia \\ E-mail: pahomova_sveta@yahoo.com
}

\begin{abstract}
Investigations of fluxes of a dissolved element across the water-sediment interface in Vistula Lagoon (Baltic Sea) were carried out in August 2001 and 2002, using chamber experiments. Oxygen, iron(II), total dissolved iron, manganese, copper and lead fluxes were calculated. For the first time the fluxes of metals bonded with organic matter of sea water were studied. The contribution of metals bonded with organic matter to the total flux was varied depending upon conditions and may reach up to $70 \%$. It was found that metal fluxes at the coastal zone are larger than at the center of the lagoon by the factor of $2-4$.
\end{abstract}

Keywords: Baltic Sea, chamber experiment, benthic fluxes, organic forms, manganese, iron species

\section{Introduction}

Studies of fluxes of some elements across the water-sediment interface were carried out in August 2001 and 2002 in Vistula Lagoon, Baltic Sea, using chamber technique. Elements of interest were oxygen and dissolved forms of manganese, iron, copper and lead.

Regions of studies reported in literature up to date are represented mostly by coastal waters with substantial anthropogenic pollution. In such conditions differences in metal concentrations and fluxes may be of several orders of magnitude: $20-$ $1200 \mathrm{mmol} \mathrm{m}^{-2}$ day $^{-1}$ for manganese; $1-150$ for iron, $0.02-2$ for copper (Berelsona, 2003; Pakhomova, 2003; Sundby, 1986; Warnken, 2001; Westerlund, 1986; Zagoa, 2000). Direct measurements of fluxes of transitional and heavy metals at the water-sediment interface are represented mainly by dissolved inorganic forms. The environment in a coastal zone is usually under anthropogenic influence and loading by big amounts of organic matter. As a consequence, behavior of dissolved metals, especially bonded with organic substances, may become an important factor of exchange between sediment and water. However, studies of this kind are practically not present in literature.

The aim of this work was investigation of fluxes of dissolved forms of metals across water-sediment interface, namely, dissolved inorganic $\mathrm{Fe}(\mathrm{II}), \mathrm{Fe}(\mathrm{III})$, $\mathrm{Mn}, \mathrm{Pb}, \mathrm{Cu}$, along with $\mathrm{Fe}, \mathrm{Mn}, \mathrm{Pb}, \mathrm{Cu}$ bonded with organic matter of seawater. Two sites were selected for the estimation of anthropogenic influence in different regions of Vistula Lagoon, at the coast and at the center of the Lagoon. Studies were carried out in 2001 and 2002 for finding out time changes in fluxes.

\section{Materials and Methods}

Within the framework of experiments carried out in August 2001, two stations were studied (stations 1.2001 and 2.2001) at the depth of $2 \mathrm{~m}$ in the central (by Nasypnoi island) and in the northern parts of Vistula Lagoon in Primorskaya Bight (Fig. 1). The chamber deployment lasted for four days. In August 2002 two stations were studied as well. The first study site was located at the same place as in 2001 (station 1.2002), and the second station was located in Primorskaya Bight, at the depth of $4 \mathrm{~m}$ (station 3.2002). Both deployments lasted the three days.

Sediments at all the stations were represented by aleurite silt. The uppermost $(0-2 \mathrm{~cm})$ sediment layer having brown tint was located over the layer of gray aleurite silt with admixtures of fine sand and lots of hydrotroilite additives. The odor of hydrogen sulfide was not observed on studied sediments.

\subsection{Sampling and sample treatment}

Four plastic cylindrical chambers (total height of $30 \mathrm{~cm}$, working height of $25 \mathrm{~cm}$, diameter of $30 \mathrm{~cm}$ ) were deployed at the bottom. Two of them were working chambers, the third was blank chamber isolated from sediment. Cups with hydroquinone were placed inside and outside of the fourth chamber for obtaining the coefficient for recalculation from a closed chamber system to the real open system of seabed. Tracing the difference in dynamics of dissolution of hydroquinone inside and outside of the chamber allowed to account for changes of hydrodynamics inside the chamber. Water samples 
were taken by divers every day using syringes (200 - $300 \mathrm{ml}$ ) and twice during the first day of deployment. The used chamber technique is described in details in (Vershinin, 1999, 2002).

All water samples were filtered through cellulose acetate filters, pore size $0.45 \mu \mathrm{m}$ prior to the analyses.

Optical absorbance was measured using a KFK-3 spectrophotometer (Russia). Electrochemical measurements were carried out using electrochemical analyzer Ecotest-VA (SPE "Econics-Expert", Moscow, Russia) with a threeelectrode cell. A thin-film mercury electrode served as a working electrode, a saturated silver chloride electrode served as a reference electrode, and platinum wire was used as an auxiliary electrode.

Oxygen was analyzed using Winkler titration technique. Dissolved inorganic manganese was determined spectrophotometrically using formaldoxyme (Marchenko, 1971). Concentration of iron(II) and total dissolved inorganic iron was determined spectrophotometrically using ferrozine (Kononets, 2003; Stookey, 1970).

\subsection{Determination of Lead and Copper using anodic stripping voltammetry (SVA)}

$20 \mathrm{ml}$ of sample was placed into the electrochemical cell, and $0.2 \mathrm{ml}$ of $0.01 \mathrm{M}$ mercury (II) chloride solution and $1 \mathrm{ml}$ of 1:1 acetic buffer solution ( $\mathrm{pH} 4.5)$ were added. Concentrations of metals were determined using standard addition technique. SVA measurements parameters: deposition and initial potential of sweep was -900 $\mathrm{mV}$, finishing potential of sweep was $+200 \mathrm{mV}$, sweep rate $100 \mathrm{mV} \mathrm{s}^{-1}$, deposition time $300-900 \mathrm{~s}$; differential pulse form of sweep was used with the pulse height of $30 \mathrm{mV}$ and pulse frequency of $25 \mathrm{~Hz}$.

\subsection{Determination of metals after organic matter decomposition}

For the determination of iron and manganese 20 $\mathrm{ml}$ of sample, $0.1 \mathrm{ml}$ of concentrated nitric acid, and $0.06 \mathrm{ml}$ of $30 \%$ water solution of hydrogen peroxide were placed into a quartz test-tube. For the determination of copper and lead $20 \mathrm{ml}$ of sample, $0.1 \mathrm{ml}$ of concentrated nitric acid, and $0.06 \mathrm{ml}$ of formic acid was placed into a quartz test-tube. Then, test-tubes were irradiated by UV lamp for $1 \mathrm{~h}$. Following determination of metals was made as described above.

Studied forms of metals are denoted as follows: dissolved inorganic iron - Fe(II), total dissolved inorganic iron $-\mathrm{Fe}_{\text {tot }}$, total dissolved iron after the decomposition of organic matter $-\mathrm{Fe}_{\mathrm{tot}} *$; total dissolved inorganic manganese $-\mathrm{Mn}_{\text {tot }}$, total dissolved manganese after the decomposition of organic matter $-\mathrm{Mn}_{\text {tot }}$ * Following forms were calculated as differences: dissolved inorganic iron(III): $\mathrm{Fe}(\mathrm{III})=\mathrm{Fe}_{\text {tot }}-\mathrm{Fe}(\mathrm{II})$, iron bonded with orgnic matter of seawater: $\mathrm{Fe}_{\text {org }}=\mathrm{Fe}_{\text {tot }}{ }^{*}-\mathrm{Fe}_{\text {tot }}$, manganese bonded with organic matter of seawater: $\mathrm{Mn}_{\text {org }}=\mathrm{Mn}_{\text {tot }} *-\mathrm{Mn}_{\text {tot }}$.

\subsection{Calculation of fluxes}

The detailed description of the calculation of fluxes was presented in (Vershinin, 1999). For evaluation of fluxes of dissolved elements on the base of chamber data we used linear approximation $J_{\text {in }}=-H \Delta C / \Delta t$, where $H-$ working height of chamber, $\Delta C / \Delta t-$ rate of change (increase) of concentration of some form of an element (in this case only first day data used), the data for two working chambers were averaged. The resulting value was calculated as difference between flux in working and blank chambers. For recalculating chamber fluxes to open seabed system (Vershinin, 1999) we used equation $J_{\text {open }}=J_{\text {in }} \times k$, where $k=\Delta m_{1}$ $\mathrm{x} t_{2} /\left(\Delta m_{2} \times t_{1}\right) ; \Delta \mathrm{m}_{1}$ and $\Delta m_{2}-$ differences between a hydroquinone cup mass prior to deployment and after incubation inside $\left(\Delta m_{1}\right)$ and outside $\left(\Delta m_{2}\right)$ of chamber; $t_{1}$ and $t_{2}$ - time of stay of hydroquinone cups underwater inside and outside of chamber, respectively.

\section{Results and discussion}

Results of chemical analyses are presented in Table 1. Calculated values of fluxes are presented in Table 2. Positive flux value indicates that flux is directed into the sediment, negative - from the sediment into seawater. Obtained flux values are in accordance with previously reported data (Berelsona, 2003; Pakhomova, 2003; Sundby, 1986; Warnken, 2001; Westerlund, 1986; Zagoa, 2000).

\subsection{Oxygen}

Chamber fluxes of oxygen were close for stations 1.2001, 1.2002 and 2.2002, $J_{\text {in }}=14,17$ and 24 mmole $\mathrm{m}^{-2} \mathrm{day}^{-1}$, respectively, that indicates similar biogeochemical conditions in chambers. Oxygen flux at the station 3.2002 was higher, 78

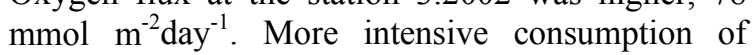
oxygen and higher fluxes of metals as will be shown further are essentially attributed to anthropogenic influence. The region of the station 3.2002 is affected by sewage of the Kaliningrad city and its harbor, and this load is subjected to tidal and weather as well as seasonal and annual changes.

After recalculating chamber fluxes to the open seabed system using the coefficients $(\mathrm{k}=7.2,6.5$, 5.7, 6.9 for stations $1.2001,1.2002,2.2001,3.2002$ respectively) obtained from the hydroquinone measurements flux values become sufficiently higher $\left(100,160,100\right.$ and $540 \mathrm{mmol} \mathrm{m}^{-2} \mathrm{day}^{-1}$, respectively). Notably that after recalculation fluxes on stations 1.2001 and 1.2002 (same study site in two years) become equal.

Under the consumption of oxygen metal concentrations increased inside working chambers, and remained almost constant inside the blank chamber. 


\subsection{Iron}

The concentration of dissolved inorganic iron in the near-bottom water at stations 1.2002 and 1.2002 was low $(<0.07 \mu \mathrm{M})$, while in Primorskaya Bight concentration of iron was noticeably higher $(0.1-$ $0.4 \mu \mathrm{M}) . \mathrm{Fe}(\mathrm{II})$ was found to be the predominating form of dissolved iron (Table 1). During chamber experiments concentrations of iron forms grew that allowed to evaluate fluxes of iron forms (Table 2).

The behavior of iron in the central and coastal parts of the Lagoon was different. On stations 1.2001 and 1.2002 (Fig. 3) increase of Fe(II) and $\mathrm{Fe}_{\text {tot }}$ was observed only for the first day of the chamber deployment.

Table 1

Concentration of elements in bottom water of Vistula Lagoon

\begin{tabular}{|c|c|c|c|c|c|c|c|c|}
\hline \multirow{2}{*}{ Station } & \multicolumn{8}{|c|}{ Element } \\
\hline & $\mathrm{O}_{2}$ & Mn & $\mathbf{M n}_{\text {tot }}{ }^{*}$ & $\mathrm{Fe}(\mathrm{II})$ & $\mathbf{F e}_{\text {tot }}$ & $\mathrm{Fe}_{\text {tot }}{ }^{*}$ & $\mathbf{C u}$ & $\mathbf{P b}$ \\
\hline 1.2001 & 224.1 & 0.29 & - & 0 & 0 & 0.23 & - & - \\
\hline 2.2001 & 268.7 & 0.37 & - & 0.28 & 0.48 & 0.49 & - & - \\
\hline 1.2002 & 283.5 & 0.7 & 3.80 & 0.05 & 0.07 & 0.44 & 14.4 & 2.88 \\
\hline 3.2002 & 292.4 & 1.22 & 4.47 & 0.12 & 0.20 & 1.05 & 10.6 & 2.24 \\
\hline
\end{tabular}

Table 2

Fluxes of dissolved elements across the water-sediment interface $\left(J_{\text {in }}\right)$.

\begin{tabular}{|c|c|c|c|c|}
\hline \multirow[t]{2}{*}{ Element } & \multicolumn{4}{|c|}{ Station } \\
\hline & 1.2001 & 2.2001 & 1.2002 & 3.2002 \\
\hline $\mathrm{O}_{2}, \mathrm{mmol} \mathrm{m}^{-2}$ day $^{-1}$ & $14 \pm 1$ & $24 \pm 1$ & $17 \pm 2$ & $78 \pm 8$ \\
\hline $\mathrm{Mn}, \square \mathrm{mol} \mathrm{m}^{-2}$ day $^{-1}$ & $-270 \pm 30$ & $-410 \pm 30$ & $-300 \pm 60$ & $-770 \pm 150$ \\
\hline $\mathrm{Mn}_{\text {tot }}{ }^{*}, \square \mathrm{mol} \mathrm{m}^{-2}$ day $^{-1}$ & - & - & $-380 \pm 20$ & $-820 \pm 200$ \\
\hline $\mathrm{Fe}(\mathrm{II}), \square \mathrm{mol} \mathrm{m}^{-2}$ day $^{-1}$ & $-90 \pm 10$ & $-50 \pm 8$ & $-26 \pm 1$ & $-170 \pm 10$ \\
\hline $\mathrm{Fe}(\mathrm{III}), \square \mathrm{mol} \mathrm{m}^{-2}$ day $^{-1}$ & $-20 \pm 8$ & $-11 \pm 5$ & $-15 \pm 6$ & $-100 \pm 30$ \\
\hline $\mathrm{Fe}_{\text {org }}, \square \mathrm{mol} \mathrm{m}^{-2}$ day $^{-1}$ & $-30 \pm 10$ & 0 & $-100 \pm 10$ & 0 \\
\hline $\mathrm{Fe}_{\text {tot }}{ }^{*}, \square \mathrm{mol} \mathrm{m}^{-2}$ day $^{-1}$ & $-140 \pm 10$ & $-61 \pm 5$ & $-140 \pm 10$ & $-270 \pm 20$ \\
\hline $\mathrm{Pb}, \mathrm{nmol} \mathrm{m}^{-2}$ day $^{-1}$ & - & - & $-90 \pm 10$ & $-1300 \pm 400$ \\
\hline $\mathrm{Cu}, \mathrm{nmol} \mathrm{m}^{-2}$ day $^{-1}$ & - & - & $-950 \pm 150$ & $-2600 \pm 300$ \\
\hline k (recalculation coeff.) & $7.2 \pm 0.3$ & $6.5 \pm 0.8$ & $5.7 \pm 0.5$ & $6.9 \pm 1$ \\
\hline
\end{tabular}

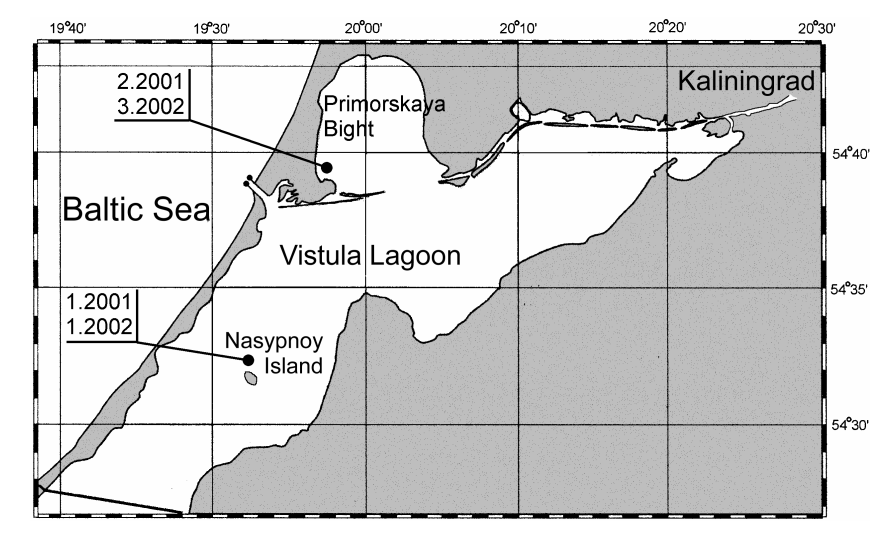

Fig. 1. Map of study sites

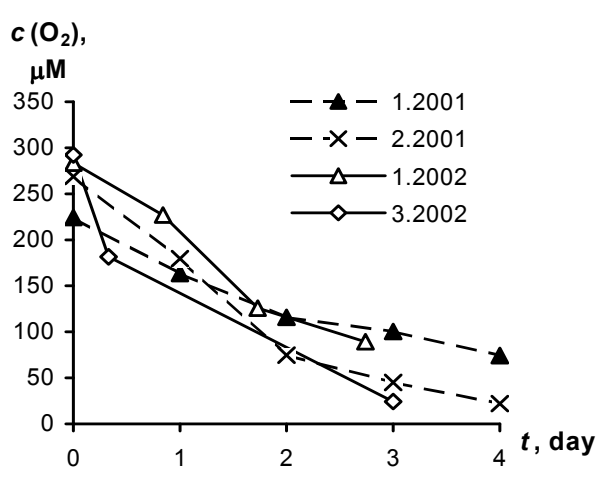

Fig. 2. Decrease of oxygen in chamber
Then, the increase stopped and iron concentration changed insignificantly during the rest time of deployment. On station 1.2001 in the initial time concentrations of $\mathrm{Fe}(\mathrm{II})$ and $\mathrm{Fe}_{\text {tot }}$ were below the detection limit (which is equal to $0.04 \mu \mathrm{M}$ ), so the initial concentrations of these forms were considered as equal to zero when calculating fluxes. Evidently that this approximation does not affect fluxes of $\mathrm{Fe}(\mathrm{II})$ and $\mathrm{Fe}_{\text {tot }}$, but does affect the flux of $\mathrm{Fe}$ (III) and may be the source of error leading to some overestimation of $\mathrm{Fe}$ (III) flux. On station
$1.2002 \mathrm{Fe}$ (III) flux appears more reliable because the concentrations of $\mathrm{Fe}$ (II) and $\mathrm{Fe}_{\text {tot }}$ in the initial time exceeded remarkably the detection limit and were equal to 0.05 and $0.07 \mu \mathrm{M}$, respectively. On both stations at the beginning of chamber experiment concentration of $\mathrm{Fe}_{\text {org }}$ was quite high, 0.27 and $0.44 \mu \mathrm{M}$ for 1.2001 and 1.2002, respectively.

In 2001 on station at the central part of the Lagoon the flux of $\mathrm{Fe}_{\text {org }}$ was low, $30 \mu \mathrm{mol} \mathrm{m}{ }^{-2}$ day $^{-1}$, and increased up to $100 \mu \mathrm{mol} \mathrm{m}^{-2}$ day $^{-1}$ in 2002 . It is 
interesting that the flux of $\mathrm{Fe}_{\text {tot }}$ * was equal to 140 $\mu \mathrm{mol} \mathrm{m} \mathrm{m}^{-2}$ day $^{-1}$ for both years, but in 2001 predominating form of iron was $\mathrm{Fe}(\mathrm{II})$, and in 2002 $-\mathrm{Fe}_{\text {org }}$. The flux of $\mathrm{Fe}(\mathrm{III})$ was low $(15-20 \mu \mathrm{mol}$ $\mathrm{m}^{-2}$ day $\left.^{-1}\right)$.

The flux of $\mathrm{Fe}_{\text {org }}$ was not detected on stations 2.2001 and 3.2002 (Fig. 4). On station 2.2001 $\mathrm{Fe}_{\mathrm{org}}$

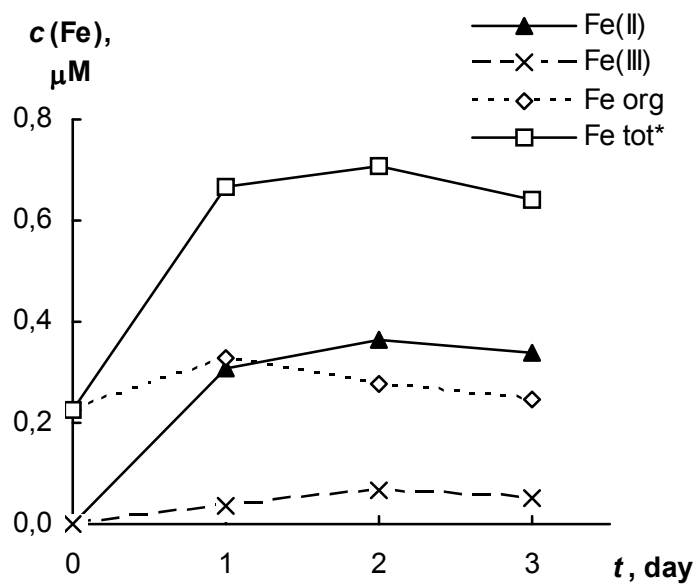

Fig. 3. The release of iron in chamber on station 1.2001

The increase of concentrations of iron forms was linear during the whole experiment on station 2.2001. Evaluating the fluxes from the sediments into the water in Vistula Lagoon one can consider that the flux of $\mathrm{Fe}(\mathrm{II})$ forms the major fraction of iron flux. The second (by the value) fraction is $\mathrm{Fe}_{\mathrm{org}}$, although the release of $\mathrm{Fe}_{\text {org }}$ may be hardly detectable under high concentrations of $\mathrm{Fe}_{\text {tot }}$ and $\mathrm{Fe}_{\text {tot }}$ *.

\subsection{Manganese}

The behaviour of $\mathrm{Mn}_{\text {tot }}$ is alike to $\mathrm{Fe}_{\text {tot }}$ for all stations. On stations 1.2001 and 1.2002 in the central part of the Lagoon fluxes of $\mathrm{Mn}_{\text {tot }}$ are similar and are equal to 270 and $300 \mu \mathrm{mol} \mathrm{m}{ }^{-2}$ day $^{-1}$, respectively (Fig. 5). Stations 2.2001 and 3.2002 have considerably higher fluxes of $\mathrm{Mn}_{\text {tot }}, 410$ and 770 $\mu \mathrm{mol} \mathrm{m}^{-2}$ day $^{-1}$, respectively, which may be attributed to anthropogenic influence. On both stations in $2002 \mathrm{Mn}_{\text {org }}$ fluxes were also investigated. Bottom water both at the central part of the Lagoon and in the Primorskaya Bight was found to contain high concentration of $\mathrm{Mn}_{\text {tot }}(3.8-4.5 \mu \mathrm{M})$. The major part of manganese is bonded with the organic matter of seawater, about $3 \mu \mathrm{M}$ (stations 2.2001 and 3.2002 , Table 1). On the contrary, the contribution of $\mathrm{Mn}_{\mathrm{org}}$ to the total flux of dissolved manganese was almost not detectable. On station $3.2002 \mathrm{Fe}_{\text {org }}$ was quite high $(0.9 \mu \mathrm{M})$ and remained constant, so flux value was insignificant. The behavior of $\mathrm{Fe}(\mathrm{II})$ and $\mathrm{Fe}_{\text {tot }}$ on station 3.2002 was similar to 1.2001 and 1.2002. The increase of these forms was not linear and slowed down during the chamber experiment.

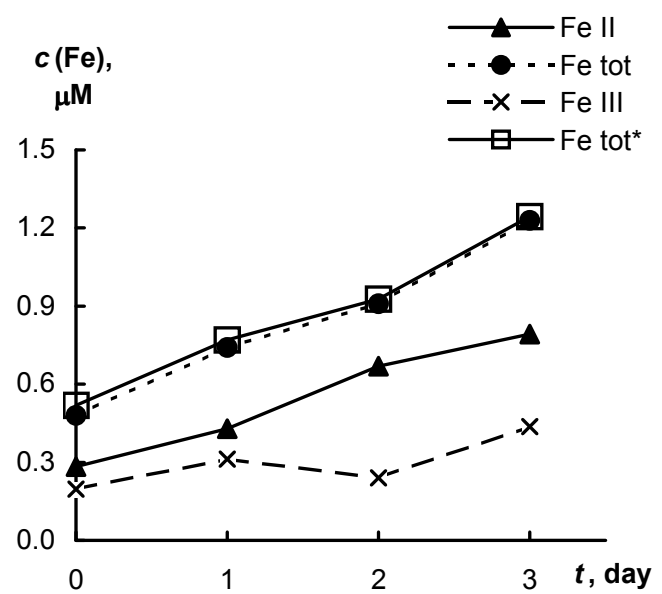

Fig. 4. Release of iron in chamber on station 2.2001

was low, $21 \%$ and $6 \%$ for stations 1.2002 and 3.2002 respectively (Table 2). The behavior of $\mathrm{Mn}_{\text {org }}$ is similar to the behavior of $\mathrm{Fe}_{\text {org }}$ for all studied stations.

\subsection{Copper}

Concentration of $\mathrm{Cu}_{\text {tot }}$ in the chambers on station 1.2002 increased linearly throughout the chamber experiment beginning from its initial value of $14 \mathrm{nM}$ which is common value for near-bottom water (Fig. 6). On station 3.2002 behavior of copper is similar to other metals, which means initial increase followed by its slow down or change to the constant value. After the decomposition of organic matter concentration of copper $\left(\mathrm{Cu}_{\mathrm{tot}} *\right)$ increased by three orders of magnitude from $7 \mathrm{nM}$ to $10 \mu \mathrm{M}$ and remained constant over the experiment, so flux of $\mathrm{Cu}_{\mathrm{tot}}$ * was insignificant.

\subsection{Lead}

The increase of lead was linear for stations 1.2002 and 3.2002 (Fig. 6). Concentration of lead did not change after decomposition of organic matter $(3-8 \mathrm{nM})$, so the flux of this toxic element bonded with organic matter is practically absent. 


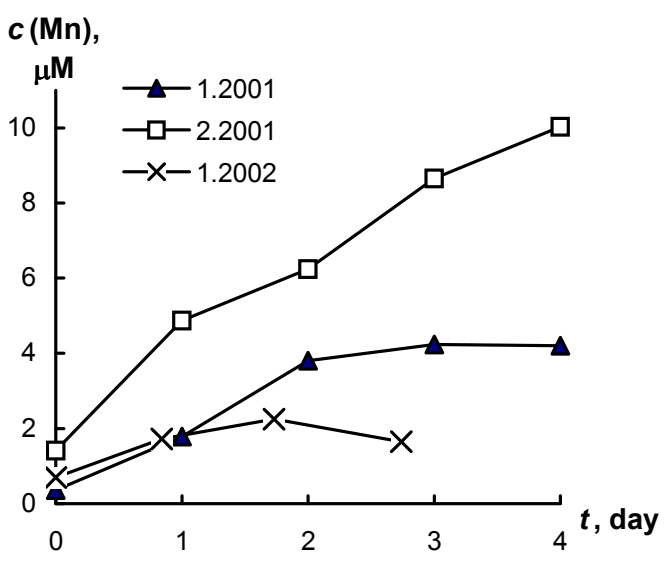

Fig. 5. Release of manganese in chamber

\section{Conclusions}

Thus, the fluxes of dissolved forms of iron, manganese, copper and lead across the bottom water-sediment interface were studied. For the first time fluxes of these metals bonded with organic substances of seawater were studied. It was found that a significant part of iron and copper, and manganese may be bonded with the organic matter of seawater. The contribution of the organically bonded form to the flux of manganese constitutes up to $20 \%$. On stations at the center of the Lagoon iron bonded with organic matter of seawater contribute to the exchange of iron, and the contribution of $\mathrm{Fe}_{\text {org }}$ to the total flux of iron increased from $21 \%$ in 2001 to $71 \%$ in 2002 due to the decrease of $\mathrm{Fe}_{\text {org }}$ contribution from $64 \%$ to $18.5 \%$. Copper was found to be almost completely bonded with the organic matter and its flux is insignificant. Lead is not complexed with organic matter. On stations located at the coastal zone under strong anthropogenic influence fluxes are $2-4$ times higher compared to the stations in the center of Vistula Lagoon.

\section{References}

Berelsona W., McManusb J., Coalec K., Johnson K., Burdige D., Kilgore T., Colodner D., Chavez F., Kudela F., Boucher J., 2003. A time series of benthic flux measurements from Monterey Bay, CA. // Continental Shelf Research. 23: 457 - 481

Kononets M. Yu., Pakhomova S. V., Rozanov A. G., Proskurnin M. A., 2002. Determination of soluble iron species in seawater using ferrozine. // Journal of Analytical Chemistry, 57(7): 586 589

Marchenko Z., 1971. Fotometric determination of elements. Moscow, Nauka: 234 - 235. (in Russian)

Pakhomova S. V., Kononets M. Yu., Yudin M. V., Rozanov A. G., 2003. Studies on the fluxes of dissolved forms of iron and manganese through the bottom water-sediment interface on the

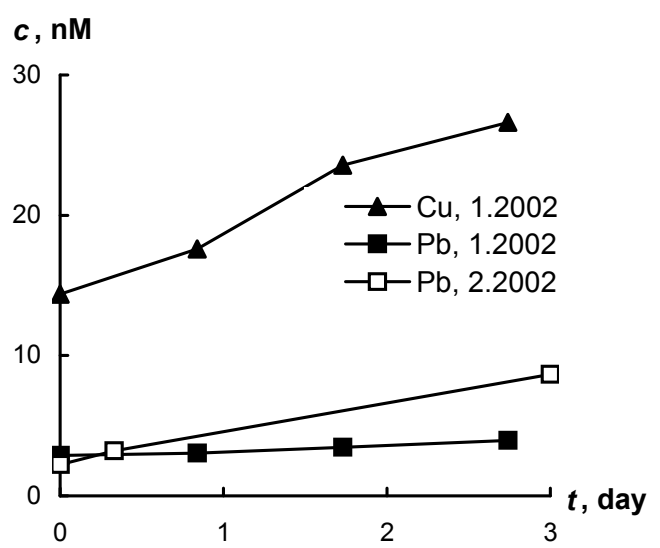

Fig. 6. Release of copper and lead in chamber

Northeastern shelf of the Black Sea. // Oceanology, 43(4): 493

Rozanov A. G., 1995. Porewater, diagenesis of sediment and chemical elements exchange at the water-sediment interface. Marine Chemistry. Moscow, Nauka: 307 - 329 (in Russian)

Rozanov A. G., Vershinin A. V., Bogdanovskaya V. V., 2001. Oxygen consumption by the coastal bottom sediments (North Caucasian sector of the Black Sea). // Oceanology, 41(5): 660

Stookey L. I., 1970. Ferrozine. A new spectrophotometric reagent for iron. // Analytical Chemistry, 42(7): 779 - 781

Sundby B., Anderson L. G., Hall P. O. J., Iverfeldt A., Rutgers van der Loeff M., Westerlund S., 1986. The effect of oxygen on release and uptake of cobalt, manganese, iron and phosphate at the sediment-water interface. // Geochimica Cosmochimica Acta, 50(6): 1281 - 1288

Vershinin A. V., Rozanov A. G., 1999. Results of the studies on chemical exchange through the bottom water-sediment interface in Gelendzhik Bay of the Black Sea. // Oceanology, 39(6): 772

Vershinin A. V., Rozanov A. G., 2002. Chemical exchange at the water-sediment interface in seas and oceans. Moscow, Geos: 162 p. (in Russian)

Warnken K. W., Gill G. A., Griffin L. L., Santschi P. H., 2001. Sediment-water exchange of Mn, $\mathrm{Fe}, \mathrm{Ni}$ and $\mathrm{Zn}$ in Galveston Bay, Texas. // Marine Chemistry, 73: 215 - 231

Westerlund S. F. G., Anderson L. G., Hall P. O. J., Iverfeldt A., Rutgers van der Loeff, M. and Sundby B., 1986. Benthic fluxes of cadmium, copper, nickel, zinc and lead in the coastal environment. // Geochimica Cosmochimica Acta, 50(6): 1289 - 1296

Zagoa C., Capodaglioa G., Ceradinic S., Ciceri G., Abelmoschi L., Soggia F., Cescon P., Scarponi G., 2000. Benthic fluxes of cadmium, lead, copper and nitrogen species in the northern Adriatic Sea in front of the River Po outflow, Italy. // Science of Total Environment, 246: 121 $-137$ 